\title{
CANIS LUPUS FAMILIARIS. SYMBOLIKA PSA W HISTORII, SZTUCE I LITERATURZE - ZARYS PROBLEMATYKI
}

Pies jest zwierzęciem towarzyszącym człowiekowi od zarania dziejów. Brał udział w polowaniach, służył jak stróż mienia, dlatego kojarzono go z cechami pozytywnymi, takimi jak wierność, oddanie, czujność, przywiązanie. Jest najstarszym udomowionym zwierzęciem i jednym z niewielu, spośród 35 gatunków z rodziny psowatych, które udało się oswoić. Oprócz psa także wilki i szakale zostały częściowo oswojone, lisy zaś należą do zwierząt hodowlanych. Pies (łac. canis lupus familiaris) jest potomkiem wilka (canis lupus). Pierwotnym miejscem udomowienia psa były Chiny, a nastapiło to ok. 25 tysięcy lat temu. Stamtąd, na skutek migracji przez Cieśninę Beringa, przedostał się wraz z człowiekiem do Ameryki Północnej. Co spowodowało, że psy zostały udomowione? Jako pierwszy podawany jest czynnik behawioralny, a więc rozwinięty u tych zwierząt respekt dla przywódcy czy poczucie hierarchii. Bardziej prozaiczny jest fakt, że psy żywiły się tym samym pokarmem co człowiek, dlatego podążały za nim. W momencie domestykacji tych zwierząt nastąpiły zmiany ich sylwetki, zwłaszcza owłosienia, przez co można wyróżnić wiele grup psów: gładkowłose, średniodługowłose, długowłose, ostrowłose, jedwabistowłose, falistowłose, kędzierzawe, kosmatowłose i bezwłose. Przez wieki zyskał szereg odniesień w kulturze i sztuce, kojarzył się i pozytywnie, i negatywnie, co zostanie prześledzone w porządku chronologicznym. Warto dodać, że jest on, obok kota, tym zwierzęciem, które jest obecne we wszystkich kulturach i wierzeniach od starożytności po dzień dzisiejszy.

Ks. dr SŁawomir FilipeK - doktor historii sztuki (23 czerwca 2020 r. - Instytut Sztuki Polskiej Akademii Nauk w Warszawie); e-mail: slv.philipek@gmail.com; ORCID: https://orcid.org/ 0000-0002-5818-9331. 


\section{EGIPT I MEZOPOTAMIA}

Przedstawienia figuralne z okresu Starego Państwa wyróżniają 12-13 psich ras, zwłaszcza z typu chartowatych, ogarowatych i szpicowatych (Wajda 151). W starożytnych znaleziskach można odnaleźć także mumie psów, często z kosztownymi obrożami, świadczącymi nie tylko o wysokim statusie majątkowym ich właścicieli, ale też o pozycji zwierzęcia (Reisner 7-9, 180182). Na podstawie analizy reliefów, malowideł i papirusowych zapisów można stwierdzić, że psy pełniły rozmaite funkcje. Były strażnikami domów, chroniły stada przy wypasie, wykorzystywano je przy łowach z udziałem rydwanów, gdy polowano na gazele i strusie, w końcu traktowano je jako domowe „maskotki” - te zapewne były balsamowane i mumifikowane. Jak podaje Herodot, w Egipcie szacunek do psów był tak wielki, że jeśli zdechło jakieś zwierzę, to właściciel golił całe ciało i głowę (Kobielus 259). Na dworze faraona funkcjonował nawet tytuł „opiekuna psów” czy „nadzorcy opiekunów psów", co świadczy o znacznej ich liczbie w pałacu władcy. W znaczeniu religijnym nie odgrywały większej roli, tę bowiem funkcję pełnił inny gatunek psowatych - szakal, poświęcony bogu Anubisowi (Kobielus 152).

W Mezopotamii hodowla psów nie była tak rozpowszechniona jak w Egipcie, o czym świadczą nieliczne wzmianki artystyczne i literackie. Jedna z notek u Herodota w Dziejach mówi o Triantajchmesie, namiestniku Babilonii, który oprócz licznych stad koni, posiadał także sfory psów indyjskich. Były one tak liczne, że cztery duże wsie zwolniono od wszystkich innych podatków, gdyż miały dostarczać żywność psom (Lasota-Moskalewska 205). W babilońskich wierzeniach pies był symbolem bogini Guli (Ninisiny), patronki zdrowia i bezpieczeństwa domu, której w ofierze składano małe kamienne lub gliniane figurki psów (il. 1.), a ją samą przedstawiano z psem u stóp (Black i Green 81-82).

\section{GRECJA I RZYM}

W starożytnej Grecji wizerunek psa ukazywany na wazach i kamieniach grobowych był symbolem wierności. Co więcej, znane są jego podobizny apotropaiczne, odpędzające złe duchy, które umieszczane na progach domów, pałaców, miejsc zamieszkania, miały chronić przed złymi mocami. Dorothea Forstner podaje, że nawet współcześnie spotyka się u Persów zwyczaj przyprowadzania psa do osoby umierającej, w celu odpędzenia zła 
(293) ${ }^{1}$. Był również stróżem świątyń czy krainy zmarłych, gdzie olbrzymi, wielogłowy Cerber strzegł wejścia do Hadesu². Stał się zwierzęciem proguprzejścia ze świata żywych do krainy zmarłych, co potem odzwierciedla się w ludowości i innych mitologiach ${ }^{3}$. Znalazło to swój wyraz również w nagrobkach średniowiecznych. Przekonanie o psie jako towarzyszu wędrówki w zaświaty znajduje się na płycie grobowej Małgorzaty i Jana von Soest czy nagrobku króla Władysława Jagiełły w katedrze wawelskiej. Podstawę nagrobka zdobią figury psów i sokołów - jest to nawiązanie do odwiecznej walki dobra i zła, gdzie symbolem duszy jest sokół, a pies oznaką grzechu, co potwierdzałby fragment Psalmu 22: „Sfora psów mnie opadła” (Ps 22,17). Badacze nie są jednak zgodni co do jednoznacznej interpretacji, niektórzy uważają, że to nawiązanie do myśliwskich zamiłowań króla, pies więc występuje tu w nowym odniesieniu symbolicznym - jako wierny towarzysz. Podobnie zatem jak na nagrobku św. królowej Jadwigi, gdzie pies leżący u jej stóp symbolizuje wierność (Błogosławiona 166).

Pies był poświęcony bogu Asklepiosowi, którego w dzieciństwie miała wykarmić suka, dlatego w jego świątyniach w Epidauros i Atenach hodowano te zwierzęta (Grimal, Stownik [wyd. 1990] 45). Zresztą znanych jest wiele motywów psa w literaturze i historii starożytnej Grecji. Psem Aleksandra Macedońskiego był Peritas, obecny u boku swego pana w czasie wielu bitew. Zginął on przygnieciony przez słonia w czasie jednej z walk. Jego ,imieniem” Aleksander nazwał jedno z miast imperium (Kistler 5). Plutarch z Cheronei w Żywotach sławnych mężów przytacza historię innego psa. Kiedy Ksantyppos, ojciec Peryklesa, uchodził z Aten do Salaminy, jego wierny pies pokonał tę drogę wpław, płynąc przy trierze. Właściciel pochował swojego towarzysza na przylądku, który od tego wziął swoją nazwę: Kynossena - Psi Grób (Plutarch 101).

Artemida, bogini łowów, używała psów do polowań. Boginię czarów i magii Hekate ukazywano jako kobietę z trzema głowami - lwa, psa i konia. Nazywano ją „czarną suką”, ponieważ były jej poświęcone wszystkie czarne psy (Simoons 233-234). Ulubioną rasą tej bogini były molosy, sprowadzane

\footnotetext{
${ }^{1}$ Persowie wyznający zaratustranizm trzymali psy w świątyniach, gdzie otaczano je najwyższym szacunkiem. Kiedy ktoś miał umrzeć, przyprowadzano do niego białego lub czterookiego psa, który miał pomóc przedostać się duszy do zaświatów, szedł też w procesji pogrzebowej. Pies opiekował się tylko dobrymi duszami i tylko takim pomagał pokonać most Cziwat. Złe dusze nie dostawały czworonożnego przewodnika; gubiły drogę i spadały z mostu w przepaść.

${ }^{2}$ Podobne konotacje ma w wierzeniach skandynawskich, gdzie psy piekielne strzegą krainy zmarłych.

${ }^{3}$ U Germanów wejścia do krainy zmarłych strzegł Garm, piekielny pies bogini Hel.
} 
z górzystej prowincji Epiru - Molozji. Szczególną więź psa i myśliwego widać w przypadku Oriona i Syriusza, których przeniesiono na sklepienie nieba - obok gwiazdozbioru Oriona znajduje się konstelacja Wielkiego Psa z Syriuszem, tzw. Psią Gwiazdą, rozpoczynającą w starożytnej Grecji ateński nowy rok (Grimal, Stownik [wyd. 2008] 262-263). Syriusz był czasem mylony z Ortosem, psem Geriona i bratem Cerbera. Grecy przyswoili wcześniejsze egipskie opowieści o Syriuszu, gdzie zgodnie z legendą psy myśliwskie Oriona - jeden duży, drugi mały - odwiecznie ścigają po niebie Zająca. Starożytni pisarze, m.in. Eratostenes i Hyginus, uważali, że Wielki Pies reprezentował Laelapsa, psa tak szybkiego, że nie umknęła mu żadna ofiara (Grant i Hazel 84). Jako symbol wierności występuje w Iliadzie Homera, gdzie pies Odyseusza, po 20 latach oczekiwania, rozpoznał swojego pana, zamienionego przez Atenę w żebraka, po czym zdechł (Kopaliński 960). Zresztą pies był także przewodnikiem Homera, który był ślepcem. Biały pies stał się tematem legendy o powstaniu świątyni Heraklesa. Obywatel ateński Diomos, składał ofiarę bogom w swoim domu. Nagle pojawił się znikąd biały pies, który porwał ofiarne mięso i uciekł. Diomos odczytał to jako proroctwo i w miejscu, gdzie pies zakopał mięso, zbudowano świą-

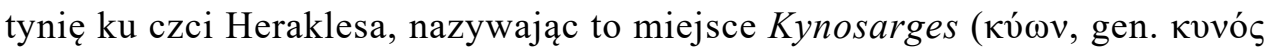

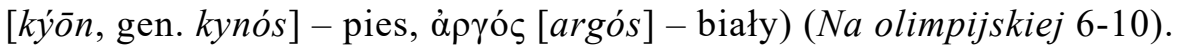

W Rzymie ceniono przede wszystkim psy myśliwskie i stróżujące. Pisarz Columella, znawca agrotechniki, w swoim dziele $O$ rolnictwie pisze o psie w sposób niezwykle pozytywny, podkreślając jego liczne cechy: „Który niewolnik jest bardziej przywiązany do swego pana? Kto jest wierniejszym towarzyszem? Czy jest bardziej nieprzekupny strażnik? Czy jest pewniejszy mściciel lub obrońca?" (Columella 7.12.2-3). Opisuje też w rzeczowy sposób, jakie psy nadają się do stróżowania $\mathrm{w}$ domu, a jakie do pilnowania stad. Okazuje się, że pies stróżujący potrafił się dostosować do każdej sytuacji, o czym donosi, cytując Arystofanesa, Caspar Barlaeus: „Excepi fures latratu, mutus amantes; Sic placui domino, sic placui dominae” - „Szczekaniem przeganiałem złodziei, ciszą sprzyjałem kochankom, jedno było miłe panu, drugie pani" (Casparis 500). Psy pełniły funkcje bojowe - chętnie szkolono je dla celów militarnych, bo jak pisał Renatus Wegecjusz „praktyka pokazała, iż korzystne jest trzymanie na wieżach groźnych psów z ostrym węchem, by wyczuwszy wroga z daleka ostrzegały szczekaniem" (Renatus 343). Eneasz Taktyk, grecki pisarz z IV wieku przed Chrystusem, autor prac poświęconych sztuce wojennej, pisał, że w Epirze wykorzystywano psy jako kurierów: „Najpierw, używając smyczy, zabierano psa od jego pana. Nakła- 
dano mu kołnierz z zaszytą wewnątrz wiadomością. W nocy, a czasami nawet $\mathrm{w}$ dzień, uwalniano zwierzę, które niezmiennie wracało tam, skąd zostało zabrane" (Eneasz 105). W Pompejach w tzw. Domu Dramaturga, niedaleko Term Rynkowych, w przedsionku znajduje się mozaika przedstawiająca psa i opatrzona napisem cave canem - „strzeż się psa” (Weeber 172 nn.) (il. 2). Takie mozaiki, pierwowzór dzisiejszych tabliczek na wejściach do posesji, znajdowały się w wielu domach rzymskich ${ }^{4}$. Wyobrażenia psów stanowiły też elementy dekoracyjne pojawiające się bardzo często na pomnikach nagrobnych. O szczególnej roli psa dla Rzymian świadczą liczne epitafia poświęcone czworonogom, zarówno pełniącym funkcje bojowe i strażnicze, jak też będących pupilami domowymi ${ }^{5}$.

Psy pojawiają się zasadniczo we wszystkich kulturach i wierzeniach. Gwoli przykładu można wspomnieć chociażby te bardziej egzotyczne. Na przykład w mitologii Eskimosów canis lupus familiaris brał udział nie tylko w stworzeniu świata, był także przewodnikiem dusz dzieci, które były zbyt nieporadne, by mogły same trafić do krainy wieczności (Read i González 172). Wiązał się z tym makabryczny zwyczaj układania $w$ dziecięcych grobach psich głów. Indianie wierzyli, że zorze to zaprzęgi psów, przewożące dusze zmarłych do innego świata. Dlatego zawsze starali się być dobrzy dla swoich zwierząt, by te nie poskarżyły się owym „podniebnym” przewoźnikom - z zemsty mogłyby przewrócić sanie $\mathrm{z}$ duszami, które przez to nie trafiłyby do krainy zmarłych, tylko błąkałyby się między światami.

\section{IZRAEL - BIBLIA}

U Izraelitów psy były pierwotnie wykorzystywane do pilnowania trzód, dopiero w okresie niewoli babilońskiej zaczęły być postrzegane jako wierni towarzysze (por. Tb 6,1). Najstarsze pochówki Izraelitów wraz z psami pochodzą $\mathrm{z}$ ok. $\mathrm{X}$ wieku przed Chrystusem. Kolejne exemplum stanowi znajdujący się w pobliżu grób mężczyzny pochowanego z dwoma udomowionymi psami. Canis miał jednak także negatywne konotacje, ze względu

\footnotetext{
${ }^{4}$ Szerzej zob. Hofmann.

${ }^{5}$ Wiele epitafiów miało szczególnie wzruszającą wymowę: „Przechodniu - mówi jedno z nich - jeśli przypadkiem idąc drogą, zauważysz ten pomnik, nie śmiej się, proszę, że jest to grób psa. Polały się łzy z jego powodu, a jego pan własnoręcznie usypał mogiłę i wyrył te słowa na płycie grobowej”. Corpus Inscriptionum Graecarum 6310 (cyt. za: Winniczuk 84).
} 
na dużą liczbę bezpańskich, głodnych i agresywnych zwierząt, które wałęsały się po Palestynie. W Biblii słowo „pies” występuje 43 razy - odnaleźć przy tym można określenie „pies” użyte w kategorii wyzwiska, a nawet obrazu ludzi bezbożnych, postępujących niemoralnie, żądnych krwi. Wspomina o tym Apokalipsa św. Jana (Ap 22, 14-15): „Błogosławieni, którzy płuczą swe szaty, aby władza nad drzewem życia do nich należała i aby bramami wchodzili do Miasta. Na zewnątrz są psy, guślarze, rozpustnicy, zabójcy, bałwochwalcy i każdy, kto kłamstwo kocha i nim żyje”. Ta negatywna metaforyka w różnych miejscach Pisma Świętego wzięła się m.in. stąd, że psy wracają do swoich wymiocin, co budziło odrazę (por. Prz 26,11 ), czy też prowadzą półdziki tryb życia, przebywając na wysypiskach śmieci, na ulicach, dla nich też przeznaczona była padlina zwierząt uduszonych, których spożywania zabraniało żydowskie prawo (Wajda 155).

W księgach historycznych „psem” posługiwano się przy rzucaniu klątwy, jak chociazby w słowach: „będą Cię żarły psy” (por. 1 Krl 14,11), co było kontynuowane w starotestamentalnych proroctwach Ozeasza $(\mathrm{Oz} 13,8)$ i Jeremiasza (Jr 15,3). Pies był wykorzystywany w tekstach mądrościowych, gdzie obrazował głupotę (Prz 26,11) ${ }^{6}$, znane jest także przysłowie: „Chwyta za uszy psa, który biegnie - kto w cudze spory się miesza” (Prz 26,17). W Księdze Samuela pies (hebr. כלב [keleb]) jest symbolem pogardy - Goliat mówi do Dawida przed walką: „Czyż jestem psem, że przychodzisz do mnie z kijem?” (1 Sm 17,43), a miano „zdechły pies” było jednym z najbardziej deprecjonujących. Przez określenie „pies” wskazywano niekiedy na prześladowców ludu Bożego („Sfora psów mnie opadła” - Ps 22,17), „zapłatą dla psów" określano zaś wynagrodzenie za męski nierząd sakralny, o czym mowa w Księdze Powtórzonego Prawa (Pwt 23,18-19): „Nie będzie nierządnicy sakralnej wśród córek Izraela ani mężczyzn uprawiających nierząd sakralny wśród synów Izraela. Nie zaniesiesz do domu Pana, Boga twego, zarobku nierządnicy, jak i «zapłaty dla psa», jako rzeczy ofiarowanej ślubem. Tak jednym, jak i drugim brzydzi się Pan, Bóg twój”.

Niemniej jednak Biblia zna również pozytywne odniesienia psa. Wielokrotnie występuje on w scenach z życia Chrystusa. Pismo Święte widzi w tym zwierzęciu symbol duchowych pasterzy, kaznodziejów. Wspomina o tym św. Grzegorz Wielki, papież, komentując perykopę Ewangelii, odnoszącą się do przypowieści o bogatym człowieku i biednym Łazarzu (Łk 16,21): „Niekiedy Pismo Święte pod nazwą psów zwykło rozumieć kazno-

\footnotetext{
${ }^{6}$ Przysłowie przywołuje św. Piotr Apostoł w swoim Liście, mówiąc o szydercach (por. 2 P
} 2,22). 
dziejów. Język bowiem psów uzdrawia rany, gdy je liżą. Tak też i święci nauczyciele, pouczając nas przy wyznawaniu grzechów, jakby leczą ranę ducha językiem jej dotykając" (Grzegorz Wielki 40,2; cyt. za: Forstner 293). $\mathrm{Z}$ kolei w św. Paweł Liście do Filipian przestrzega przed fałszywymi nauczycielami, mówiąc: „Strzeżcie się psów, strzeżcie się złych pracowników, strzeżcie się okaleczeńców”, gdzie psy oznaczają zwolenników powrotu na judaizm. W końcu określenia psa, konkretnie szczeniąt - gr. $\kappa v-$ vópıov [kynárion] - używa sam Chrystus w rozmowie z kobietą kananejską, proszącą o uzdrowienie córki, nazywając tak pogan, w odróżnieniu od dzieci - Izraelitów: „On jednak odparł: «Niedobrze jest zabrać chleb dzieciom, a rzucić psom». A ona odrzekła: «Tak, Panie, lecz i szczenięta jedzą z okruszyn, które spadają ze stołów ich panów»" (Mt 15,26-27). W sztuce przedstawiano później to spotkanie z udziałem psów, rzadziej ukazując same szczenięta.

\section{ŚREDNIOWIECZE I NOWOŻYTNOŚĆ - MOTYWY W SZTUCE, PISMACH, HAGIOGRAFII}

W malarstwie religijnym, podejmującym tematy biblijne, pies występuje w znaczeniu zarówno pozytywnym, jak i negatywnym. Jako wierny towarzysz pojawia się w scenach podróży do Raga w Medii Tobiasza Młodszego i archanioła Rafała (choć jest to tylko wzmianka), także w scenach pokłonu Trzech Króli, pokłonu pasterzy (il. 3.) czy symbolizując wierność małżeńską, np. w dziele Dawid i Batszeba Jana Massysa z 1562 r. Pies, mający przekaz negatywny, pojawia się przy okazji Ostatniej Wieczerzy, leżąc u stóp Judasza lub goniąc kota, jest tu symbolem wrogości (Knipping 192).

Często spotyka się motyw psa w miniaturach i tkactwie. Przykładem są alegoryczne przedstawienia sceny Zwiastowania poprzez łączenie Biblii z legendą o jednorożcu. W tych przedstawieniach często Archanioł Gabriel wiedzie na smyczy cztery psy: Misericordia, Veritas, Iustitia, Pax (jak w Psalmie 85) i nagania nimi jednorożca na łono Matki Bożej (Forstner 294). $\mathrm{W}$ bestiariuszach pies jest wzorem roztropności i wierności. Przedstawienia krzyżowców z psami podkreślały ich czyste, dobre intencje i wierność Bogu (Szczepanowicz i Mrozek 37). Owo zwierzę jest przedstawiane także jako symbol zachłanności - pies trzyma w pysku kość, przechodząc przez wodę dostrzega swoje odbicie, sądząc, że jest to kolejna porcja jedzenia, wypuszcza z pyska trzymaną kość i rzuca się łapczywie na „nowy kąsek”, 
widziany w lustrze wody (Kobielus 260). Symbolizuje zatem ludzi bezrozumnych, ignorantów i zachłannych, którzy pragnąc coraz więcej, tracą nawet to, co mają. Ten motyw wykorzystał Jean de la Fontaine w bajce o Psie puszczajacym zdobycz dla cienia:

Każdy jakieś ma złudzenie.

Niezliczone wielkie masy

Szaleńców goniących cienie

Są i będą po wsze czasy.

Ci są do psa podobni, o którym w Ezopie

Czytamy, że kęs mięsa niosąc, jego postać

Kiedy spostrzegł na wodzie, skoczył, by ją dostać,

Kęs puściwszy i mało nie ugrzązł w roztopie,

Ledwie do brzegu dopłynął.

I kęs przepadł i cień zginął. (Lafontaine 176)

Według jednej z opowieści o mędrcu talmudycznym, który modlił się, by psy mogły śpiewać na chwałę Pana, ukazujący mu się anioł objawił, że Bóg szczególnie upodobał sobie psy - te bowiem nie szczekały, gdy Izraelici opuszczali Egipt (Wj 11,7). Miało to oznaczać błogosławieństwo Boże i zapowiedź, że Naród Wybrany będzie wolny od nieszczęść. O tym, że pies może mieć pozytywne i negatywne znaczenie, świadczą wypowiedzi św. Augustyna. Uznał on psa za symbol heretyka, na innym miejscu określa tak męczenników za wiarę, nazywając ich psami szczekającymi w obronie swojego Pana - Jezusa (Kobielus 259). Pisze o tym także św. Ambroży w Hexaemeronie:

A co powiem o psach, w których naturze leży okazywanie wdzięczności i pilnej czujności dla dobra swych panów? Stąd do tych, którzy zapominają o doznanych dobrodziejstwach i są leniwi i gnuśni Pismo woła: Psy nieme, szczekać nie mogące. A więc są psy, które potrafią szczekać w obronie swych panów, umieją bronić swe domostwa. A więc i ty naucz się podnosić głos w obronie Chrystusa, gdy na owczarnię Chrystusową napadają groźne wilki. (Cyt. za: Zgraja 831)

Dla wielu uczonych średniowiecza psy są symbolami fałszywych kaznodziejów (chociaż przeważa pogląd o dobrych nauczycielach), a także niewiernych, prześladujących świętą wiarę - jest więc to kontynuacja biblijnego patrzenia i tamtej symboliki. Psa można postrzegać w znaczeniu kapłaństwa ministerialnego (urzędowego), co szeroko omawia ks. Krzysztof Bardski, podając wskazania na różne zwierzęta („Kapłaństwo” 303-314). Łączy to z metaforą Chrystusa Dobrego Pasterza - w jej kontekście psy oznaczają 
tych, którzy pomagają Pasterzowi w utrzymaniu porządku w trzodzie oraz bronią jej przed wilkami (heretykami). Opat Absalom z Springiersbach napisał, komentując werset 24 Psalmu 76, że:

pies jest dla domowników przedmiotem pieszczot, a na obcych szczeka, wilka kąsa, językiem leczy i w nocy sumiennie trzyma straż. Jeśli to wszystko odnieść do przełożonych i podwładnych, metaforycznie pod psy można podstawić rządców Kościołów, domownicy zaś to zachowujący doskonale porządek, obcymi są ci, którzy ze słabości naruszają regułę, przez wilków rozumie się uparcie przekraczających prawo. (Bardski, „Symbolika” 97).

Inny tekst - przypowieść o Łazarzu - wskazuje na leczenie ran w sakramentach. Według Godfryda z Admont dotyczy to zwłaszcza sakramentu pojednania: dzięki słowu i posłudze kapłana sam Chrystus leczy nawet najbardziej gnijące rany grzechu (Bardski, „Symbolika” 98).

Pies pojawia się dosyć często jako atrybut hagiograficzny. Lucyna Rotter podaje, że jest on atrybutem 24 świętych i błogosławionych. Tu znalazł pozytywne odniesienia, w kontekście negatywnego biblijnego symbolu obżarstwa, zła, ciemnych mocy czy bezbożności. Św. Hildegarda postrzegała psy jako wrogów szatana (Cooper 202-205). Pisała, że „szatan nienawidzi psa i ucieka przed nim ze względu na jego wierność wobec człowieka" (Kowalewska 62).

Motyw psa znany jest przez całe średniowiecze. Matka św. Dominika we śnie ujrzała oczekiwane dziecko jako biało-czarnego pieska niosącego pochodnię, która zapala świat. Pies był oczywiście symbolem wierności, a pochodnia - światłem wiary i gorliwości. Nie bez znaczenia jest też gra słowna: dominikanie - Domini canes - „psy Pańskie”. Z podobną historią mamy do czynienia w przypadku św. Bernarda z Clairvaux. Jego matka również miała proroczy sen, będący zapowiedzią powołania jej syna

Otóż gdy jeszcze nosiła w łonie trzeciego z kolei syna, właśnie Bernarda, miała sen wróżebny. Zdawało się jej, że ma w łonie szczekającego szczeniaka, widziała go pokrytego białą sierścią z rudawą plamą na grzbiecie. Sen ten opowiedziała pewnemu świątobliwemu mężowi, a ów rzekł jej głosem proroczym: Zostaniesz matką doskonałego szczenięcia, które będzie stróżem domu bożego i zawzięcie będzie ujadać przeciwko jego wrogom: będzie mianowicie znakomitym kaznodzieją i wielu ludzi uzdrowi leczącym wpływem swej wymowy. (de Voragine 352)

U innych świętych pies pojawia się jako zwierzę przynoszące pokarm, tak np. u św. Szymona Stocka i św. Rocha, któremu liże rany, gdy święty choruje na dżumę. W większości przypadków stanowi symbol wierności Bogu, jak u św. Ferdynanda, męczennika Kukufasa z przełomu III i IV w., św. Mał- 
gorzaty z Kortony, której pies pomógł odnaleźć zwłoki kochanka, czy francuskiego pustelnika św. Walaryka (Rotter 129). Służy także jako atrybut świętych: Henryka Suzo, Huberta, Wendelina czy Eustachego, a więc tych, którzy byli pasterzami, łowczymi, trudnili się myślistwem? ${ }^{7}$.

W ikonografii wschodniej św. Krzysztofa znane są jego wyobrażenia

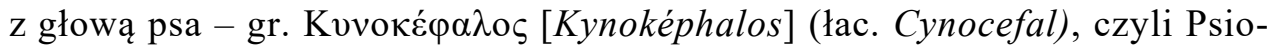
głowy, jak bowiem podaje tradycja, należał do psiogłowych ludożerców ${ }^{8}$ i został nawrócony przez św. Bartłomieja (Kobielus 262). Psiogłowi zostali już opisani w IV w. p.n.e. przez greckiego historyka i lekarza Ktezjasza w dziele $O$ Indiach, Pliniusz w Historii naturalnej opisuje ich jako lud indyjski, porozumiewający się szczekaniem, żyjący w grotach i ubierający się w skóry zwierzęce. Źródła średniowieczne mówią o nich nawet jako o kanibalach. Według irlandzkich legend św. Krzysztof urodził się jako psiogłowy olbrzym, poganin o imieniu Reprobus (z łac. niegodny, fałszywy). Wyrażać miał jednak skruchę z powodu swego pochodzenia, a po chrzcie ogromną radość z przemiany w człowieka. Legendy rosyjskie są nieco odmienne - mówią o wyjątkowej urodzie św. Krzysztofa. Chcąc uwolnić się od zalotów dziewcząt, Krzysztof poprosił Boga o oszpecenie, a ten w odpowiedzi obdarzył go twarzą psa9.

„Świętym” psem był Guinefort, czczony od XII wieku we Francji. Według legendy pies zginął z rąk własnego pana - rycerza, gdy ten zobaczył go stojącego przy kołysce dziecka i zbroczonego krwią. Dopiero po zabiciu psa zorientował się, że ten nie gryzł dziecka, ale uśmiercił węża, który próbował wejść do kołyski. Gdy właściciel zrozumiał swój błąd, pochował psa w studni, a wkoło niej posadził gaj. W krótkim czasie mieszkańcy okolicznych osad zaczęli otaczać to miejsce czcią, ponieważ jeszcze w XIII wieku zamek został zniszczony, w czym miejscowi dostrzegli boską interwencję. Uznawszy Guineforta za męczennika, prosili go o wstawiennictwo jako patrona i uzdrowiciela dzieci. Chore dzieci przynoszono do grobu, składano ofiarę z soli, wieszano dziecięce ubranka oraz pieluchy i przekazywano między drzewami dziewięć razy nagie niemowlę starej kobiecie, która opiekowała się tym miejscem. Inne obrzędy obejmowały pozostawianie nagich dzieci na słomie między świecami do czasu, aż te się wypalą, oraz zanu-

\footnotetext{
${ }^{7}$ Zob Frątczak; Kuźmak szp. 1270; Mandziuk 169-178.

${ }^{8}$ Pisze o tym Marco Polo w Opisaniu świata, wspominając, że mieszkańcy jednej z wysp niedaleko Indii mieli psie głowy oraz oczy i zęby jak pies (Marco Polo 359).

${ }^{9}$ Niezwykle popularne były ikony z przedstawieniem psiogłowego św. Krzysztofa, z czym od XVII wieku walczyła prawosławna Cerkiew na ziemiach rosyjskich, zakazując bezskutecznie przedstawień świętego w taki sposób.
} 
rzanie ich w pobliskiej rzece (Scotland 44-48). Pomimo wielu wysiłków inkwizycji i Kościoła na rzecz wyplenienia tego kultu utrzymywał się on aż do XIX wieku. W niektórych tradycjach Guineforta uważano za psa św. Rocha, który do zamku rycerza miał trafić po śmierci swojego poprzedniego pana. Istnieje teoria o utożsamieniu prawdziwego św. Guineforta, którego kult rozwinął się w Pawii, a którego też wspominano 22 sierpnia jako patrona chorych dzieci, z wyżej opisanym zwierzęciem ${ }^{10}$.

Psy w sztuce nowożytnej stanowią niezwykle interesujący temat dzieł malarskich ze względu na różnorodność motywów, mnogość psich ras umieszczanych na płótnie. $Z$ tego też względu omówię kilka najbardziej charakterystycznych wizerunków psa w malarstwie, przywołując artystów, którzy poświęcali czworonogom wiele miejsca w swojej twórczości. W sztuce renesansu powszechnym motywem są sceny polowań z chartami. Jednym z ciekawszych przykładów jest obraz włoskiego artysty Paolo Uccello z $1470 \mathrm{r}$. (il. 4), ukazujący nocną scenę polowania w lesie z ogromną liczbą rycerzy na koniach i psów myśliwskich (Kemp 164-178).

Tycjan maluje psy w scenach mitologicznych, aktach czy portretach. Na szczególną uwagę zasługuje portret Karola V. Odtąd motyw króla z psem u boku będzie kontynuowany w twórczości innych artystów. Diego Velázquez namalował Portret Filipa IV w stroju myśliwskim, a Francisco Goya przedstawił tak Karola III (Sureda 120). Velázquez namalował jeszcze dwa portrety o tematyce łowieckiej: Książe Baltazar Karol w stroju myśliwskim i Kardynat infant Ferdynand w stroju myśliwskim - na obu obrazach łowczym towarzyszą psy myśliwskie. Jego trzy obrazy wykazują liczne podobieństwa: postaci przedstawione są w niemal naturalnych rozmiarach, na świeżym powietrzu, w stroju myśliwskim i strzelbą w ręce. Pies pojawia się również w dziele Las Meninas, które prezentuje hiszpańską rodzinę królewską z dworem (Witko 83). Flamandzki malarz doby baroku Antoon van Dyck namalował znany obraz przedstawiający najstarsze pięcioro dzieci Karola I (Brown passim), na płótnie ukazano również dwa psy kontrastujące ze sobą - ogromnego psa rasy molosskiej oraz niewielkiego reprezentanta rasy king charles spaniel. Dyck namalował wielu członków rodziny królewskiej, liczne portrety reprezentacyjne, przedstawienia dzieci, często z psami, głównie rasy spanieli ${ }^{11}$.

Zdarza się, że ustalenie daty powstania obrazu i uwiecznionego na nim wizerunku psa pozwala uszczegółowić proces kształtowania się danej rasy.

\footnotetext{
${ }^{10}$ Szerzej na temat zob. Schmitt.

${ }^{11}$ Między innymi Portret Jacques'a Le Roy'a, 1631. Portret Jamesa Stuarta, 1633-1634, czy Portret Thomasa Wentwortha, 1632-1633.
} 
Oglądając ryciny Albrechta Dürera i późniejsze obrazy Rembrandta, możemy prześledzić formowanie się konkretnej rasy, jaką jest sznaucer ${ }^{12}$.

Psy od nowożytności stawały się symbolami odwagi, wierności i lojalności. Odzwierciedla to fakt, że w 1688 r. mops został oficjalnym psem holenderskiej rodziny królewskiej - Huis van Oranje-Nassau, a około 1736 r. tajnym symbolem Zakonu Mopsa (Mopsorden), masońskiego ugrupowania kobiet (Frick 244).

Jednym z częściej portretowanych i występujących w obrazach ras psów jest lwi piesek, rasa należąca do grupy psów zwanej „pupilami do towarzystwa". Pojawia się już w sztuce połowy XV wieku na obrazach, gobelinach, grafice i rysunkach, m.in. u Albrechta Dürera, Lucasa Cranacha Starszego czy Jana Brueghela.

Jednym z bardziej rozpoznawalnych malarzy psów, ale również koni, jeleni i niedźwiedzi, jest Edwin Henry Landseer (1802-1873), od którego nazwiska nazwano rasę psów landseerów. Jego najpopularniejszy obraz, zatytułowany A Distinguished Member of the Humane Society („Godny członek ludzkiej społeczności”) (il. 5) z 1831 r. (Najmanová i Humpál 88-89), został rozpowszechniony w tysiącach reprodukcji, przez co spopularyzował tę rasę w całej Europie. Jego niezwykłe obrazy nowofunlandczyków, mastifów alpejskich i innych ras zyskały uznanie nawet królowej Wiktorii, dla której wykonał wiele portretów, również z psami.

Wśród XX-wiecznych artystów znana jest malarka psów Lilian Cheviot, a jej słynny obraz Come Over Here! z 1915 r. przedstawia trzy psy, których losy są nieodłącznie związane z Wielką Brytanią (Secord 426). Po lewej stronie obrazu widać majestatycznego buldoga angielskiego, poniżej znajdują się dwa teriery - szkocki i walijski. Z nieco innym przesłaniem przedstawiono psy w cyklu „Psy grające w pokera” (Dogs Playing Poker) - serii szesnastu obrazów olejnych autorstwa amerykańskiego malarza Cassiusa Marcellusa Coolidge'a, zamówionych w 1903 r. przez firmę Brown \& Bigelow na potrzeby kampanii reklamowej cygar. Zauważono również, że niektóre pozy przyjmowane przez psy na malowidłach Coolidge'a zostały zaczerpnięte z prac innych artystów, takich jak Caravaggio, Georges de La Tour czy Paul Cézanne, w których twórczości znalazły się przedstawienia ludzi grających w karty. Początkowo obrazy miały służyć celom prześmiewczym i ukazywać absolutny brak gustu wśród amerykańskiej klasy robotniczej. Pies jest obecny w znanych dziełach, takich jak Święty Hieronim w swojej

${ }^{12}$ Wśród nich: Dürer, Madonna z Dzieciątkiem wśród zwierząt, 1503, czy Rembrandt, Śpiący pies, ok. 1640. 
pracowni Dürera, Chrystus myjący stopy uczniów Tintoretta, Śmierci Adonisa Rubensa, Uczcie weselnej $w$ Kanie Boscha, Polowaniu Carracciego i wielu innych ${ }^{13}$.

W malarstwie polskim tematyka psa stanowi również niezwykle bogaty obszar. Najczęściej psy występują w scenach polowań, niezwykle popularnych w XIX wieku, a także na portretach. Jednym z najsłynniejszych dzieł Wojciecha Kossaka jest Wyjazd na polowanie w Gödöllö - na obrazie widzimy cesarza Franciszka Józefa na koniu oraz sforę psów myśliwskich, która wybija się na pierwszy plan. Kossak jest również autorem portretu dziewczynki z psem, siedzącej w fotelu. Inni malarze, jak choćby Piotr Michałowski, animalista i batalista, jest autorem Portretu syna z psem, a także Stajennych z końmi i psem czy Studium białego psa. Juliusz Holzmuller, wybitny malarz koni, wykonał także akwarele z przedstawieniami psów. Wśród polskich artystów podejmujących w malarstwie ten motyw są także: Teodor Axentowicz (Dama z pieskiem), Tadeusz Makowski (Pięcioro dzieci z psem), Józef Chełmoński (Polowanie chłopskie), Alfred Wierusz-Kowalski (Psy przy saniach, Psy myśliwskie). Pies wabiący się Stróż był ulubionym psem Henryka Rodakowskiego. Zapewne z tego względu malarz zachował nieprawdopodobną wnikliwość i precyzję w odmalowywaniu anatomicznych szczegółów jego ciała. Tułów zwierzęcia pięknie kontrastuje z jego czarną głową rozświetloną przez wąską strzałkę. Najciekawszym elementem dzieła są jednak oczy, a właściwie ich brak. Cień pada w taki sposób, że oczy są właściwie niezauważalne, a odbiorca może jedynie wyobrażać sobie, jakie instynkty targają psem (Kitowska 183).

Nie sposób nie wspomnieć o psie Fryderyka Pautscha - Boro, który został namalowany przez artystę w 1928 r. (il. 6). Boro, pies rodziny Pautschów, siedzi na fotelu, wsparty na przednich łapach (por. Saint-Gaudens).

Pies w rzeźbie pojawia się rzadziej, aczkolwiek występuje już od czasów rzymskich. Stanowi symbol wierności, jak np. pies Dżok z pomnika na bulwarze Czerwieńskim w Krakowie. Znana historia głosi, że pies czekał na swojego pana, który w tragicznych okolicznościach zmarł na zawał serca w pobliżu ronda Grunwaldzkiego. Dokarmiany przez mieszkańców Krakowa, budził zdziwienie i sympatię. Po około roku oczekiwania pozwolił się przygarnąć nowej właścicielce, Marii Müller. Kobieta zmarła w 1998 r., zwierzę zaś uciekło i, wałęsając się po terenach kolejowych, zginęło pod kołami

${ }^{13}$ Chociaż pies nie jest głównym bohaterem tych obrazów, stanowi ważny element sztafażu. Różnorodność ras umieszczonych na płótnach artystów stanowi ważny element w badaniach nad pochodzeniem i pojawianiem się kolejnych psich ras. 
jadącego pociągu (Terakowska 1,12-13). Pomnik Bronisława Chromego, odsłonięty w 2001 r., był trzecim pomnikiem psa na świecie. Pomniki upamiętniają psy jako symbole poświęcenia w wojnach, akcjach ratunkowych, pomocy w czasach kataklizmów, symbol wierności swemu panu i oddaniu w służbie człowieka - m.in. japoński pies Hachiko i włoski Fido, czworonogi bezskutecznie wyczekujące właścicieli, którzy zmarli w czasie wykonywania swoich obowiązków służbowych ${ }^{14}$.

Barry był psem ratowniczym rasy bernardyn, który przez większość życia służył w schronisku na Przełęczy Świętego Bernarda w Alpach Zachodnich. Czworonóg miał uratować ponad 40 osób - zaginionych i zasypanych przez lawiny ${ }^{15}$. Pod koniec swojego życia trafił do Berna. Po śmierci ciało zostało spreparowane i wypchane, a następnie przeniesione do hallu głównego $\mathrm{Mu}$ zeum Narodowego w Bernie. Wykonawszy odlew gipsowy, szwajcarzy przekazali „zwłoki” psa do Cimetière des Chiens, nieopodal Paryża. Tam też ustawiono pomnik dzielnego psa-ratownika (Nussbaumer 46).

\section{LUDOWOŚĆ}

W polskiej tradycji ludowej pies zachował obydwa odniesienia - z jednej strony nawiązywał do bóstw chtonicznych, łączony ze śmiercią i złymi mocami, z drugiej jednak uchodził za wiernego sługę człowieka. Czasem widziano w nim wcielenie samego szatana, o popularności tego postrzegania świadczy ballada napisana przez Juliusza Słowackiego i Antoniego Odyńca, opisująca nocne rozterki dwóch wędrowców, którzy pytają na widok psa: „Czy to pies, czy to bies?"16. Szczególnie czarny pies mógł kryć w sobie różne istoty demoniczne - topielcy i demony wirujące, o wściekłym psie mówiono, że jest opętany przez złego ducha (Kolberg Dzieła wszystkie. Lubelskie 130). Postrzegany był także jako pośrednik między człowiekiem a „tamtym światem”, dlatego miał posiadać zdolność wyczuwania obecności

${ }^{14}$ Historia psa Fido i jego wierności wobec pana była tematem wielu artykułów i reportaży w prasie włoskiej i zagranicznej w latach 40. XX wieku. Por. „Fido champion de fidélité”. Paris Match, nr 450, 23 novembre 1957, s. 667.

${ }^{15}$ Napis na nagrobku głosi:

„Barry z Wielkiej Przełęczy Świętego Bernarda

Uratował czterdziestu ludziom życie

Zabił go czterdziesty pierwszy".

${ }^{16}$ Wiersz J. Słowackiego i A. Odyńca został opublikowany we Lwowie w 1909 r. Wiersz nosi tytuł Nie wiadomo co, czyli Romantyczność. Epilog do ballad. 
złych duchów, o czym informował swoich zachowaniem. Oskar Kolberg podaje, że w Lubelskiem: „Widziano [...] psy, które na cień swój od księżyca za każdem poruszeniem naszczekiwali, a przecie byli tacy, co mówili, że pies wtenczas złego ducha obracał" (Kolberg Dzieła wszystkie. Lubelskie 130). Prócz tego psy wyczuwały nadchodzącą śmierć, co sygnalizowały szczekaniem w kierunku domu lub do ziemi, były też zwierzętami mediacyjnymi, wykorzystywanymi przy przewidywaniu przeszłości. Świadczy o tym wiele obrzędów ludowych. Panny, wykonując wróżby matrymonialne w Nowy Rok czy na św. Andrzeja, zwracały uwagę na reakcje psów, wierząc, że skąd dobiega szczekanie, stamtąd przybędzie przyszły mąż. W Beskidzie Sądeckim dziewczęta rzucały gałki z chleba oznaczone męskimi imionami - ta, którą pies zjadł jako pierwszą, zwiastowała imię przyszłego męża (Kwaśniewicz 13). Zapowiedzią staropanieństwa był pies przyśniony w noc andrzejkową (Mosio i Skoczeń-Marchewka 200). Miał także znaczenie magiczne na Lubelszczyźnie matki kąpały chore dzieci w ziołach, a następnie wylewały wodę po kapieli na cudze psy, by chorobę „wyniosły z domu” (Kolberg Dzieła wszystkie. Lubelskie 130). Psy zapobiegały urokom - popularnym zażegnaniem tego było powiedzenie „na psa urok”, mówione po pomyślnym zdarzeniu, mogącym wszelako ściągnąć nieszczęście.

W końcu miały znaczenie lecznicze, co wzięte było już ze starożytności, a później średniowiecza - polizanie ran przez psa miało przyspieszać gojenie. Już św. Ambroży pisał: „Każde chore zwierzę zostaje uleczone po wypiciu krwi psa" (Ambroży 199). Albert Wielki uważał, że wisiorki z psich zębów zapobiegają żółtaczce i sprawiają, że psy nie szczekają - stąd noszą je nocni złodzieje (Kobielus 262). Hipokrates w swych pismach rekomendował dość kontrowersyjną metodę leczniczą, wedle której rozkrojony bądź rozćwiartowany pies, którego poszczególne części ciała zostaną przyłożone do głowy niewiasty, pozwoli jej wyleczyć się z melancholii (Hippocrates 143).

Co więcej, stosowano na różne schorzenia psie sadło - notabene używane były, i są także uzywane do dziś, sadła $\mathrm{z}$ innych zwierzą ${ }^{17}$. Jedno z podań ludowych widzi psa (wraz z kotem) jako dobroczyńców człowieka:

${ }^{17}$ Oskar Kolberg pisał, że w Krakowskiem ,psie sadło uważane było za jedno ze skutecznych lekarstw na oberwanie, czy podźwignienie, wlewane bywa wrzące do piwa, mleka, wódki itd. Wiara w ogóle w skuteczność wszelkiego sadła tak dalece była jeszcze do niedawna upowszechnioną, że niektórzy aptekarze, by zbyt licznie zgłaszających się zaspokoić pacyentów, każdemu z żądających czy to sadła psiego, czy wilczego, czy wieprzowego, zajęczego, borsuczego itd. dawali z jednego i tegoż samego zawsze słoja brane jakieś sadło generalnie" (Kolberg, Dzieła wszystkie. Krakowskie 106). 
Kota i psa trzeba szanować, bo z ich to łaski mamy dziś zboże. Na początku, po stworzeniu świata, wielka była wszystkiego obfitość, a zboże miało kłosy tak długie, jak całe źdźbła słomy [...] Gdy człowiek zgrzeszył, Pan Bóg [...] począł swe dary niszczyć. Wziąwszy więc palcami za słomę, omusnął już z niej zboże aż do długości dzisiejszych kłosów, gdy wtem ujrzał nadbiegających psa i kota, a niechcący żeby to niewinne zwierzęta poginęły z głodu, zatrzymał się i z litości pozostawił dla nich resztę kłosa. (Kolberg Dzieła wszystkie. Chetmskie 180)

\section{PIES W HERALDYCE, SFRAGISTYCE, NUMIZMATYCE I NA ZNACZKACH POCZTOWYCH}

Ważną sferą ikonografii psa i jego symboliki jest heraldyka, i to zarówno kościelna, jak i świecka, czy bardziej nowoczesne środki przekazu, jak znaczki pocztowe. Problem psa na polskich znaczkach poruszył ks. Józef Marecki, zauważając, że po raz pierwszy pies na znaczku w Polsce pojawia się już 1938 r. Przełomem jest rok 1963, kiedy 23 marca pojawia się dziewięcioznaczkowa seria „rasy psów”, kontynuowana w 1969 r., poprzez osem kolejnych i dwadzieścia lat później, w serii sześciu znaczków z psami myśliwskimi (Marecki 324-325).

Z kolei heraldyka w ciągu wieków wytworzyła niezwykle bogatą sferę symboliki psa. W herbach i godłach kościelnych pojawia się, rzecz jasna, $\mathrm{u}$ dominikanów $\mathrm{w}$ jednej $\mathrm{z}$ wersji herbu ${ }^{18}-\mathrm{z}$ trzymaną $\mathrm{w}$ pysku gorejącą pochodnią. Pochodnia symbolizuje gorliwość w przekazywaniu prawd ewangelicznych, pies zaś to obraz wierności i czujności w zachowywaniu czystej nauki Kościoła (Kolak i Marecki 64). Jest to także godło mówiące - od łacińskiej nazwy Domini canes. W herbach szlacheckich występuje jako klejnot w herbie Pobóg (chart), Kuszaba (osiem głów szczenięcych, srebrnych w dwóch rzędach), Korczak (pół szczenięcia wyżła) (Znamierowski 118).

W numizmatyce i medalierstwie wizerunek psa jest znany od najdawniejszych czasów. Jedne z pierwszych wizerunków to monety z VI wieku przed Chrystusem z Krety czy Sycylii ukazujące bojowe charty, psy wykorzystywane do polowań, także według legend święte psy strzegące miast.

${ }^{18} \mathrm{~W}$ dzisiejszej, częściej stosowanej wersji używa się herbu przedstawiającego w polu tarczy stylizowany krzyż, z ramionami zakończonymi motywem lilii, dzielącymi ją na cztery biało-czarne pola. 


\section{PODSUMOWANIE}

Tematyka „psia” w kulturze i sztuce jest niezwykle bogata. Pies, wierny przyjaciel człowieka, domownik, towarzysz polowań, strażnik domu, pupil do zabaw, towarzyszył człowiekowi od początków historii. W każdej kulturze, zwłaszcza tych starożytnych, zyskiwał sobie szczególne miejsce - na dworze faraonów, a także w panteonie bogów w Egipcie czy pośród bogów greckich, jako ich towarzysz. Był obecny w życiu bogatych i biednych, wykorzystywany do różnorakich celów. Nie dziwi także bogata symbolika biblijna, która w Starym Testamencie ma - co ciekawe - znaczenie negatywne, zastąpione później wykładnią pozytywną w Nowym Testamencie, u Ojców Kościoła i w hagiografii. Pies był zatem nie tylko symbolem wierności, oddania, ofiarności i odwagi, ale też symbolem rozwiązłości, chciwości, zachłanności, wrogości, co ukazano we wcześniejszym wywodzie, odwołując się do licznych motywów biblijnych i artystycznych.

Bogactwo psa w sztuce jest tym większe, że istnieje wiele setek ras psów, każdą z nich można by było omówić syntetycznie, wskazując na zmiany w wyglądzie, chociażby przez pryzmat analizy historyczno-sztucznej obrazów. Liczne wskazania na ludowe znaczenie psa w wierzeniach, magii, a nawet leczeniu, prezentują go jako zwierzę niezwykłe. Pojawia się również w takich sferach, jak heraldyka, numizmatyka, sfragistyka, a także znaczki pocztowe i medale. Dzisiejsza kultura masowa wytworzyła szereg nowych odniesień psa w filmie, literaturze, komiksie, animacji (Lassie, Biały Kieł, Szarik, Lampo, Pluto, Reksio, Beethoven, Cywil, Komisarz Rex, Komisarz Alex), łącząc w sobie bogactwo symboliki wypracowane przez wieki, zwłaszcza ikony wierności i oddania.

\section{BIBLIOGRAFIA}

Ambroży. Hexaemeron. Tłum. Władysław Szołdrski, wstęp Andrzej Bogucki, oprac. Wincenty Myszor. Wydawnictwo Akademii Teologii Katolickiej, 1969.

Bardski, Krzysztof. „Kapłaństwo ministerialne w biblijnej symbolice teriomorficznej starożytności i średniowiecza”. Verbum Vitae. Pótrocznik Biblijno-Teologiczny, nr 17, 2010, ss. 303-314.

Bardski, Krzysztof. „Symbolika kapłaństwa w obrazach biblijnych”. Warszawskie Studia Teologiczne, t. 23, z. 1, 2010, ss. 89-104.

Black, Jeremy, i Anthony Green. Słownik mitologii Mezopotamii. Wydawnictwo Książnica, 2006.

Błogosławiona Jadwiga Królowa w oczekiwaniu na kanonizację. Katalog wystawy w Muzeum Archidiecezjalnym w Krakowie. red. Józef A. Nowobilski, Wydawnictwo „Czuwajmy”, 1997. 
Brown, Christopher. Antonie Van Dyck 1599-1641. RCS Libri, 1999.

Casparis Barlaei med. doct. ac philosophiae in ill. Amstel. Gymnasio dum uiveret professoris Epistolarum liber. Pars prior. Amstelodami, 1667.

Columella, Lucius Iunius Moderatus. O rolnictwie. Tłum. Ireneusz Mikołajczyk, t. 2. Wydawnictwo Uniwersytetu Mikołaja Kopernika w Toruniu, 1991.

Cooper, Jean C. Zwierzęta symboliczne i mityczne. Tłum. Leszek Ryś i Anna Kozłowska-Ryś. Dom Wydawniczy Rebis, 1998.

De Voragine, Jakub. Złota legenda. Tłum. z jęz. łac. Janina Pleziowa. Wyboru dokonał, wstępem i przypisami opatrzył Marian Plezia, Instytut Wydawniczy Pax, 1983.

Eneasz Taktyk. Obrona oblężonego miasta. Przeł. Bogdan Burliga, Prószyński i S-ka, 2007.

„Fido champion de fidélité”. Paris Match, nr 450, 23 novembre 1957, s. 667.

Forstner, Dorothea. Świat symboliki chrześcijańskiej. Przekład i oprac. Wanda Zakrzewska, Paweł Pachciarek i Ryszard Turzyński, Instytut Wydawniczy Pax, 1990.

Frątczak, Wojciech. Patroni myśliwych. Wydawnictwo Duszpasterstwa Rolników, 2002.

Frick, Karl Richard Hermann. Licht und Finsternis. Gnostisch-theosophische und freimaurerischokkulte Geheimgesellschaften bis zur Wende des 20. Jahrhunderts, t. 2. Marix, 2005.

Grant, Michael, i John Hazel. Dictionnaire de la mythologie. Marabout, 1955.

Grimal, Pierre. Słownik mitologii greckiej i rzymskiej. Tłum. Maria Bronarska i in. Wydawnictwo Ossolineum, 1990.

Grimal, Pierre. Słownik mitologii greckiej i rzymskiej. Tłum. Maria Bronarska i in. Wydawnictwo Ossolineum, 2008.

Grzegorz Wielki. Homilie na ewangelie. Tłum. Władysław Szołdrski, wstęp Jacek Stanisław Bojarski, oprac. Mieczysław Maliński, Wydawnictwo Akademii Teologii Katolickiej, 1969.

Hippocrates. Thum. William Henry Samuel Jones, Harvard University Press, 1959.

Hofmann, Jürgen. Cave Canem. Roman aus dem alten Rom. Greifenverlag zu Rudolstadt, 1983.

Kemp, Martin, Ann Massing, Nicola Christie i Karin Groen. „Paolo Uccello's 'Hunt in the forest'”. The Burlington Magazine, nr 133 (1056), March 1991, ss. 164-178.

Kistler, John M. Animals in the Military. From Hannibal's Elephants to the Dolphins of the U.S. Navy. ABC-CLIO, 2011.

Kitowska, Małgorzata. „Album Pałahickie Henryka Rodakowskiego”. Polska Sztuka Ludowa Konteksty, t. 38, z. 3, 1984, ss. 183-188.

Knipping, John B. Iconography of the Counter Reformation in the Netherlands, vol. 2: Heaven on Earth. B. de Graaf/Sijthoff, 1974.

Kobielus, Stanisław, Bestiarium chrześcijańskie. Zwierzęta w symbolice i interpretacji. Starożytność $i$ średniowiecze. Instytut Wydawniczy Pax, 2002.

Kolak, Wacław, i Józef Marecki. Leksykon godeł zakonnych. Wydawnictwo „Adi”, 1994.

Kolberg, Oskar. Dzieła wszystkie. (Lud. Jego zwyczaje, sposób życia, mowa, podania, przystowia, obrzędy, gusła, zabawy, pieśni, muzyka i tańce), t. 34: Chetmskie. Obraz etnograficzny, cz. 2. Z materiałów pośmiertnych wydał I. Kopernicki, 1981.

Kolberg, Oskar. Dzieła wszystkie. (Lud. Jego zwyczaje, sposób życia, mowa, podania, przysłowia, obrzędy, gusła, zabawy, pieśni, muzyka i tańce), t. 7: Krakowskie. cz. 3, 1962.

Kolberg, Oskar. Dzieła wszystkie. (Lud. Jego zwyczaje, sposób życia, mowa, podania, przysłowia, obrzędy, gusła, zabawy, pieśni, muzyka i tańce), t. 17: Lubelskie, cz. 2, 1962.

Kopaliński, Władysław. Słownik mitów i tradycji kultury. Oficyna Wydawnicza RYTM, 2003. 
Kowalewska, Małgorzata. „Hildegarda z Bingen o człowieku i jego braciach mniejszych”. Ethos, nr 102, 2013, ss. 45-67.

Kuźmak, Krystyna. „Hubert”. Encyklopedia Katolicka, t. 6. Towarzystwo Naukowe KUL, 1993, szp. 1270.

Kwaśniewicz, Krystyna. „Rok obrzędowy”. Studia z kultury ludowej Beskidu Sadeckiego, red. Anna Kowalska-Lewicka. Wydawnictwo Ossolineum, 1985.

Lafontaine, Jean. Bajki. Przeł. i objaśnił Stanisław Komar, wstęp Lidia Łopatyńska. Wydawnictwo Ossolineum, 1954.

Lasota-Moskalewska, Alicja. Zwierzęta udomowione $w$ dziejach ludzkości. Wydawnictwa Uniwersytetu Warszawskiego, 2005.

Mandziuk, Józef. „Św. Hubert. Patron myśliwych podkarpackich”. Resovia Sacra. Studia Teologiczno-Filozoficzne Diecezji Rzeszowskiej. t. 14-15, 2007-2008, ss. 169-178.

Marco Polo. Opisanie świata. Tłum. Anna Czerny, wyd. 3, Państwowy Instytut Wydawniczy, 1993.

Marecki, Józef. „Zwierzęta w polskiej filatelistyce okresu PRL-u. Ssaki”. Symbol-znak-przestanie. Symbolika zwierząt, red. Józef Marecki i Lucyna Rotter, Wydawnictwo UNUM, 2009, ss. 317-348.

Mosio, Grażyna, i Beata Skoczeń-Marchewka. „Symbolika zwierząt w polskiej kulturze ludowej”. Symbol - znak - przestanie. Symbolika zwierząt, red. Józef Marecki i Lucyna Rotter, Wydawnictwo UNUM, 2009.

Na olimpijskiej bieżni i w boju. Z Pauzaniasza ,Wędrówki po Helladzie” księgi V, VI i IV. Tłum. Janina Niemirska-Pliszczyńska, Wydawnictwo Ossolineum 1968.

Najmanová, Diana, i Zděnek Humpál. Psy rasowe. Tłum. T.S.L., Państwowe Wydawnictwo Rolnicze i Leśne, 1987.

Nussbaumer, Marc. Barry vom Grossen St. Bernhard. Naturhistorisches Museum der Burgergemeinde Bern, 2000.

Plutarch. Żywoty sławnych mężów. Tłum. Mieczysław Brożek. Wstęp i objaśnienia Tadeusz Sinko, wyd. 4, Wydawnictwo Ossolineum 1955.

Read, Kay Almere, i Jason González. Handbook of Mesoamerican Mythology. Oxford University Press, 2004.

Reisner, George A. „Ancient King Gives Dog A Royal Burial”. The American Kennel Gazette, vol. 55, no. 5 (may 1938), ss. 7-9, 180-182.

Renatus, Flavius Vegetius. „Zarys wojskowości ksiag cztery”. Wstęp i thum. Anna Maria Komornicka. Meander, t. 29, nr 7-8, 1974, ss. 333-352.

Rotter, Lucyna. „Zwierzęta jako atrybuty świętych”. Symbol - znak-przesłanie. Symbolika zwierząt, red. Józef Marecki i Lucyna Rotter, Wydawnictwo UNUM, 2009, ss. 117-144.

Saint-Gaudens, Horner. Twenty-fifth international exhibition of paintings. Carnegie Institute Pittsburgh, October 14-December 5-1926. Catalogue, 1926.

Schmitt, Jean-Claude. Le saint lévrier. Guinefort, guérisseur d 'enfants depuis le XIII siècle. Flammarion, 1979.

Scotland, Jan. „Ein Windhund namens Guinefort”. Unsere Windhunde, nr 1, 2011, ss. 44-48.

Secord, William. Dog Painting. A History of the Dog in Art, wyd. 2, Antique Collectors' Club, 2009.

Simoons, Frederick J. Eat not this flesh. Food avoidances from prehistory to the present. University of Wisconsin Press, 1994. 
Sureda, Joan. Los mundos de Goya. Lunwerg Editores, 2008.

Szczepanowicz, Barbara, i Andrzej Mrozek. Atlas zwierząt biblijnych. Miejsce w Biblii i symbolika. Wydawnictwo WAM, 2007.

Terakowska, Dorota. „Epitafium na śmierć psa”. Przekrój, nr 18, 3 maja 1998, ss. 1, 12-13.

Wajda, Anna Maria. Szkice z biblijnego zwierzyńca. Wydawnictwo Petrus, 2016.

Weeber, Karl-Wilhelm. Alltag im alten Rom. Ein Lexikon. Artemis \& Winkler Verlag, 1998.

Winniczuk, Lidia. Ludzie, zwyczaje i obyczaje starożytnej Grecji i Rzymu. Wydawnictwo Naukowe PWN, 1983.

Witko, Andrzej. Tajemnica Las Meninas, wyd. 2, Wydawnictwo AA, 2020.

Zgraja, Brunon. „Stworzenia nierozumne wezwaniem do doskonałości. Przyczynek do studium nad Hexaemeronem św. Ambrożego". Vox Patrum, 32, t. 57, 2012, ss. 821-837.

Znamierowski, Alfred. Herbarz rodowy. Świat Książki, 2004.

\section{CANIS LUPUS FAMILIARIS. \\ SYMBOLIKA PSA W HISTORII, SZTUCE I LITERATURZE \\ - ZARYS PROBLEMATYKI}

\section{Streszczenie}

Pies towarzyszy człowiekowi od zarania dziejów. Brał udział w polowaniach, służył jak stróż mienia, pupil do zabaw, dlatego kojarzono go z cechami pozytywnymi, takimi jak wierność, oddanie, czujność, przywiązanie. Przez wieki zyskał szereg odniesień w kulturze i sztuce, mających charakter tak pozytywny, jak i negatywny. Warto zaznaczyć, że jest on, obok kota, tym zwierzęciem, które jest obecne we wszystkich kulturach i wierzeniach od zarania dziejów po dzień dzisiejszy. Już w starożytności zyskał szczególne miejsce na dworze faraonów, a także w panteonie bogów w Egipcie czy pośród bogów greckich, jako ich towarzysz. Był obecny w życiu bogatych i biednych, wykorzystywany do różnorakich celów. Nie dziwi także bogata symbolika biblijna, która, co ciekawe, w Starym Testamencie ma znaczenie negatywne, zastąpione później wykładnią pozytywną w Nowym Testamencie, u Ojców Kościoła i w hagiografii. Pies był zatem nie tylko symbolem wierności, oddania, ofiarności i odwagi, ale też symbolem rozwiązłości, chciwości, zachłanności, wrogości, co ukazano w niniejszym wywodzie, odwołując się do różnych motywów biblijnych i artystycznych. Wierzenia ludowe podkreślają znaczenie psa $\mathrm{w}$ gusłach, magii, a nawet leczeniu, prezentując go jako zwierzę niezwykłe. Pojawia się on również w takich sferach, jak heraldyka, numizmatyka, sfragistyka, a także znaczki pocztowe i medale. Dzisiejsza kultura masowa wytworzyła szereg nowych odniesień do psa w filmie, literaturze, komiksie, animacji, łącząc w sobie bogactwo symboliki wypracowane przez wieki, zwłaszcza ikony wierności i oddania.

Slowa klucze: pies; kultura; sztuka; malarstwo; literatura; historia; religia; symbolika.

\section{CANIS LUPUS FAMILIARIS. \\ THE SYMBOLISM OF THE DOG IN HISTORY, ART AND LITERATURE: AN OVERVIEW}

\section{S u m m ary}

The dog has accompanied humans ever since the dawn of time. It has taken part in hunting, served as a guardian of property, and as a pet for entertainment. It has been associated with 
positive qualities such as loyalty, devotion, vigilance and attachment. Over the centuries, it has gained a number of representations in culture and art, both positive and negative. It is worth noting that, besides the cat, it is the only animal which has appeared in all cultures and beliefs from the dawn of time down to the present day. In antiquity, it had already gained a special place in the court of the pharaohs, as well as in the pantheon of the gods in Egypt or among the Greek gods as their companion. It was present in the lives of the rich and the poor, and was used for various purposes. Not surprisingly, the rich biblical symbolism, which, interestingly, in the Old Testament, has negative overtones, was later replaced by positive interpretations in the New Testament, the writings of the Church Fathers, and hagiographies. The dog has thus been not only a symbol of fidelity, devotion, self-sacrifice and courage, but also one of licentiousness, greed and hostility, as is shown in this study, which makes reference to various biblical and artistic themes. Folk beliefs emphasise the importance of the dog in witchcraft, magic and even healing, presenting it as an unusual animal. It is also featured in such spheres as heraldry, numismatics, sphragistics, and on postage stamps and medals. Today's mass culture has produced a number of new references to the dog in film, literature, comics and animation, all of which combine the wealth of this symbolism developed over the centuries, especially as icons of fidelity and devotion.

Keywords: dog; culture; art; painting; literature; history; religion; symbolism. 


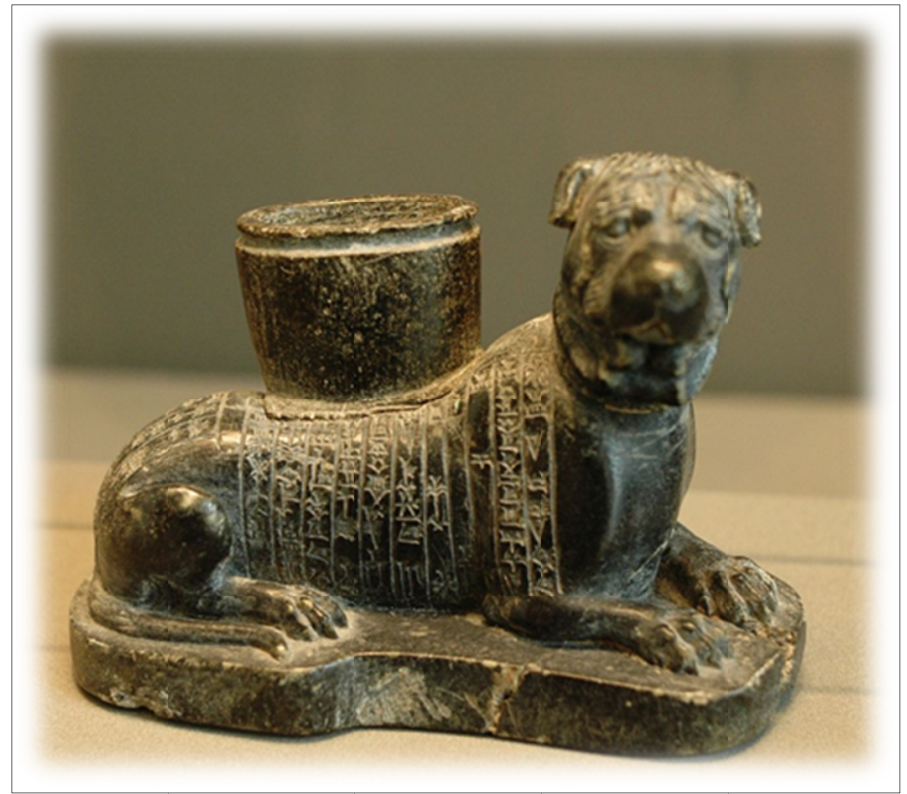

1. Autor nieznany, Figurka ofiarna psa dla bogini Guli, XIX wiek p.n.e., Paryż, Musée du Louvre

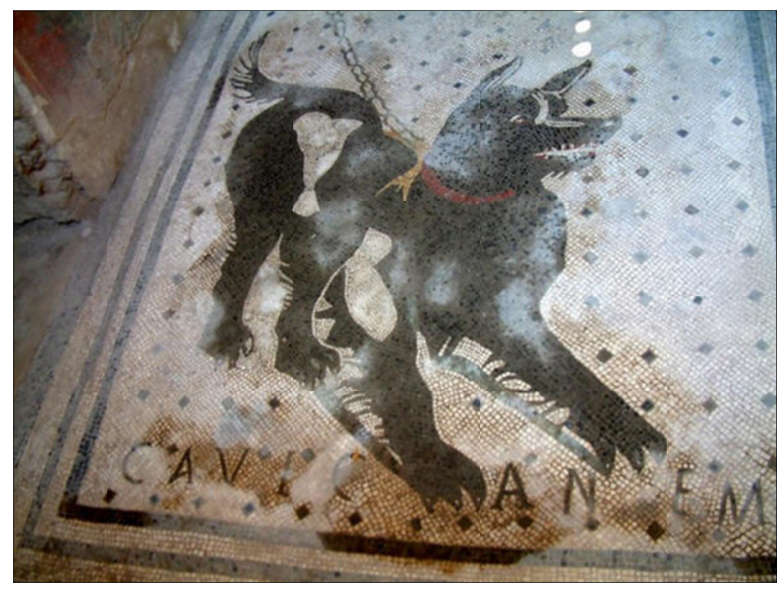

2. Autor nieznany, Pies na mozaice pompejańskiej, I wiek p.n.e., Pompeje, Dom Dramaturga (Casa del Drammaturgo) 


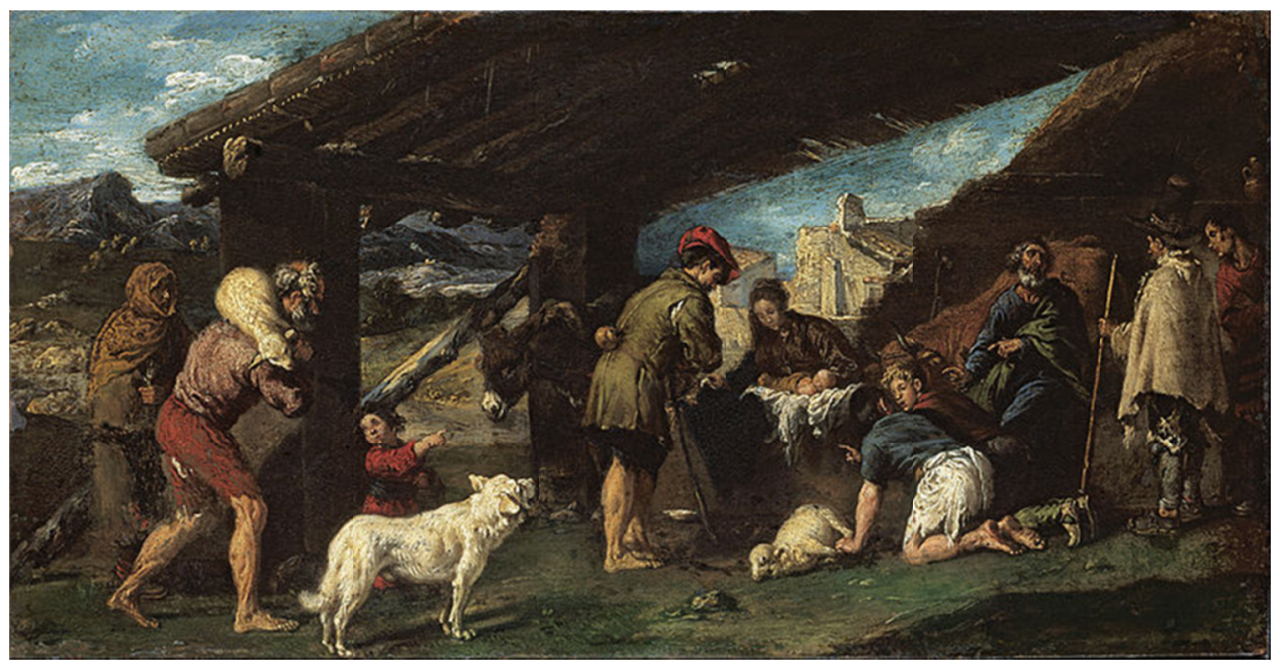

3. Juan Ribalta, Adoracja pasterzy, ok. 1620, Bilbao, Museo de Bellas Artes de Bilbao

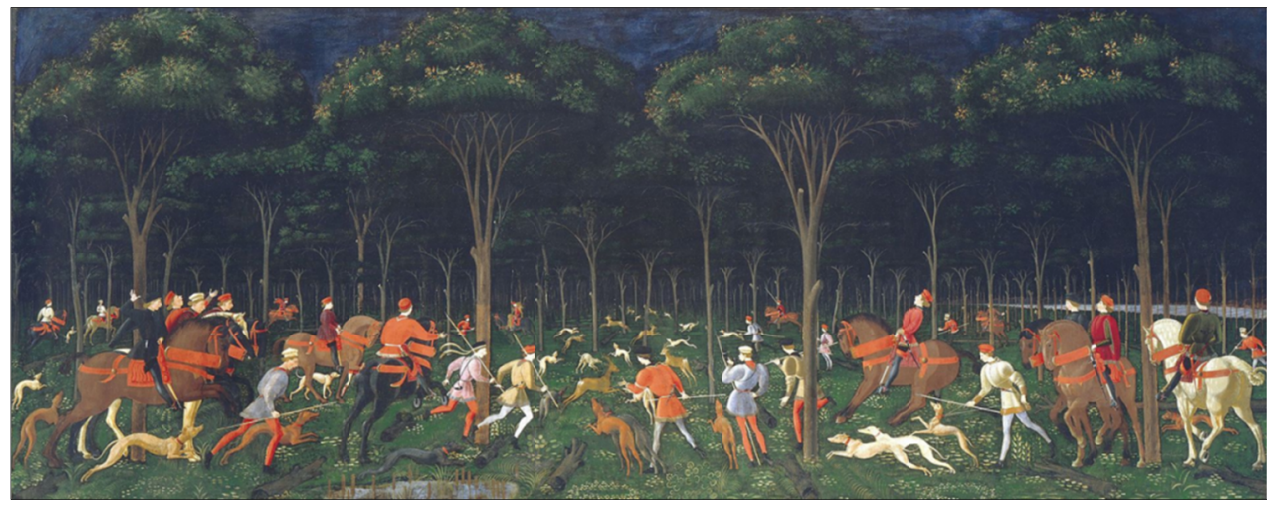

4. Paolo Uccello, Polowanie noca (Polowanie, Polowanie w lesie), ok. 1470, Oxford, Ashmolean Museum 


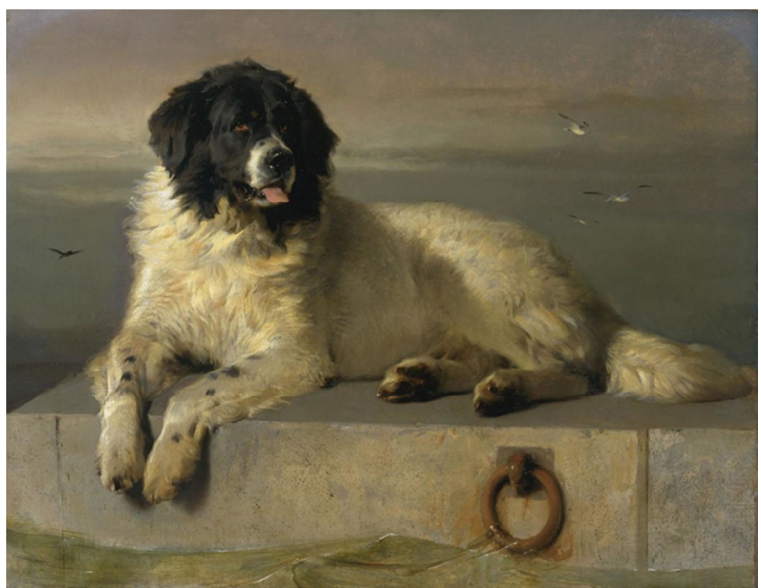

5. Edwin Landseer, A Distinguished Member of the Humane Society, 1831, Londyn, Tate Collection

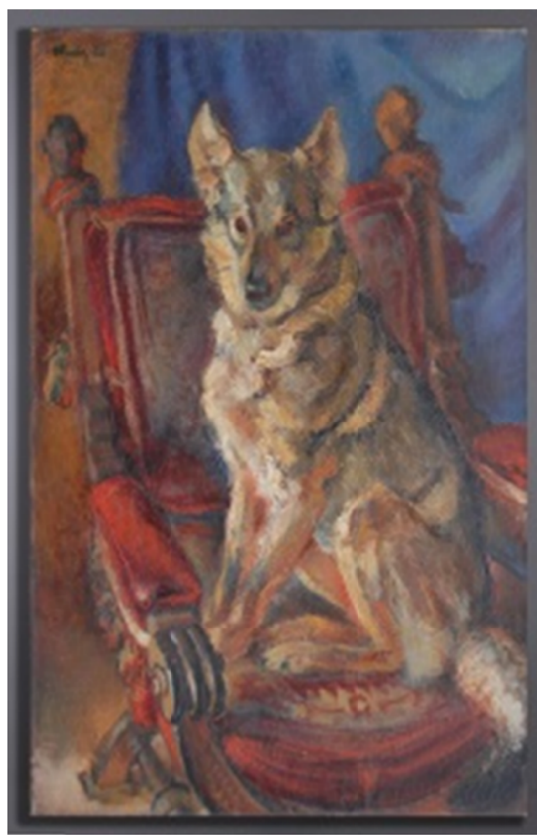

6. Fryderyk Pautsch, Wilk (Boro), 1928, Kraków, Muzeum Archidiecezjalne 